\title{
Potensi Interaksi Obat Antituberkulosis dan Antidiabetes terhadap Efek Samping Obat pada Pasien Tuberkulosis-Diabetes Melitus di RSUD Al- Ihsan Bandung
}

\author{
Rahma Ratu Halima, ${ }^{1}$ Santun Bhekti Rahimah, ${ }^{2}$ Asep Saefulloh, ${ }^{3}$ \\ Yuke Andriane, ${ }^{4}$ Endang Suherian ${ }^{5}$ \\ ${ }^{1}$ Program Studi Pendidikan Dokter, Fakultas Kedokteran, Universitas Islam Bandung \\ ${ }^{2}$ Bagian Farmakologi Fakultas Kedokteran, Universitas Islam Bandung \\ ${ }^{3}$ Bagian Saraf, Fakultas Kedokteran, RSUD Al-Ihsan \\ ${ }^{4}$ Bagian Farmakologi Fakultas Kedokteran, Universitas Islam Bandung \\ ${ }^{5}$ Program Pendidikan Fakultas Kedokteran, Universitas Islam Bandung
}

\begin{abstract}
Pengobatan tuberkulosis (TB) dengan diabetes melitus (DM) pada pasien TB-DM membutuhkan waktu yang cukup lama dan beragam sehingga memiliki risiko tinggi menyebabkan potensi interaksi obat dan menimbulkan efek samping obat. Penelitian ini bertujuan mengetahui hubungan potensi interaksi obat antituberkulosis dengan obat antidiabetes pada pasien TB dengan DM di Poli DOTS RSUD Al-Ihsan pada periode April-Mei 2018. Penelitian ini dilakukan dengan metode analitik observasional menggunakan pendekatan cross-sectional, pengambilan data obat yang terdapat pada rekam medik dan kuesioner yang telah dilakukan uji validitas dan uji reliabilitas. Data potensi interaksi obat diolah dengan memasukkan data obat yang dikonsumsi pasien menggunakan software pada LexiInteract. Subjek berjumlah 30 responden dipilih secara total sampling. Hasil penelitian menunjukkan frekuensi tertinggi potensi interaksi obat antituberkulosis-obat antidiabetes pada derajat berat sejumlah 12 dari 30 pasien. Efek samping yang terjadi pada pasien dengan frekuensi tertinggi adalah derajat ringan sejumlah 10 dari 30 pasien. Analisis dengan uji chi-square tidak memiliki nilai kemaknaan antara potensi interaksi obat dan efek samping obat $(p=0,146)$. Simpulan, tidak terdapat hubungan potensi interaksi obat dengan efek samping yang timbul pada pasien TB dengan DM di Poli DOTS RSUD Al-Ihsan periode April-Mei 2018.
\end{abstract}

Kata kunci: Diabetes melitus, efek samping obat, potensi interaksi obat, tuberkulosis

\section{Potential Interactions between Anti Tuberculosis Drug and Anti Diabetes Drug with Side Effects on Tuberculosis-Diabetes Mellitus Patients in RSUD Al-Ihsan Bandung}

The medication of tuberculosis (TB) with diabetes mellitus (DM) on TB-DM patients requires quiet a long and diverse time, so it has a high risk to potentially causing a medicine interaction and produce side effects. The research aimed to know the relation of potential interactions between anti tuberculosis medicine and anti diabetes drug with side effects on TB-DM patients in Directly Observed Treatment Short-course (DOTS) outpatient clinic of RSUD AlIhsan Bandung in April-May 2018. This research was done by cross sectional approach method by taking the drug data in the medical records and questionnaires which have been tested for validity and reliability. Data of potential drug interactions is processed by entering data of drug consumed by patient using software on Lexi-Interact. The subjects were 30 respondents, selected by total sampling. The results showed the highest frequency of potential anti-tuberculosis drug anti-diabetic drug interactions on severe degree 12 of 30 patients. The results also showed that the side effects occurring in patients with highest frequency were mild degrees of 10 of 30 patients. The analysis obtained by chi square test between potential drug interaction with side effect of drug is not having any meaning value with $(\mathrm{p}=0.146)$. In conclusion, there is no relation between potential drug interaction and side effect on TBDM patients in Directly Observed Treatment Short-course (DOTS) outpatient clinic of RSUD Al-Ihsan Bandung in April-May 2018.

Key words: Diabetes mellitus, potential drug interaction, side effects of drug, tuberculosis

Korespondensi: Rahma Ratu Halima. Prodi Pendidikan Sarjana Kedokteran, Fakultas Kedokteran, Universitas Islam Bandung, Jalan Taman Sari No. 22, 40116, Kota Bandung, Provinsi Jawa Barat, HP: 081312387500 E-mail: rahmarathal@yahoo.com. 


\section{Pendahuluan}

Tuberkulosis adalah penyakit infeksi menular yang disebabkan oleh bakteri Mycobacterium tuberculosis yang dapat menyerang berbagai organ terutama paru. Prevalensi di dunia masih tinggi khususnya di negara yang berkembang. ${ }^{1}$ Data World Health Organization (WHO) pada tahun 2017 diperkirakan terdapat 10,4 juta kasus TB di seluruh dunia. ${ }^{2}$ Berdasar atas Data dan Informasi (Infodatin) kesehatan profil kesehatan Indonesia tahun 2016 menunjukkan bahwa penderita TB di Indonesia 298.128 jiwa. Informasi dari Profil Kesehatan Indonesia menyatakan bahwa penderita TB di Jawa Barat berjumlah 52.328 jiwa. ${ }^{3}$ Diabetes melitus (DM) adalah penyakit gangguan metabolik menahun akibat pankreas tidak memproduksi cukup insulin atau tubuh tidak dapat menggunakan insulin yang diproduksi secara efektif. Jumlah penyandang DM di seluruh dunia diperkirakan sebanyak 285 juta orang. International Diabetes Foundation (IDF) 2015, diperkirakan jumlah DM di Indonesia sekitar 9,1 juta orang. Berdasar atas riset kesehatan dasar pada tahun 2013 baru sekitar 30\% penderita DM yang terdiagnosis di Indonesia. ${ }^{4}$

Penatalaksanaan pengobatan TB-DM sama dengan penderita TB paru, tetapi lebih sulit terutama karena ada beberapa hal penting yang harus diperhatikan, yaitu interaksi obat anti-TB (OAT)-obat antidiabetes (OAD) dan efek samping obat. Interaksi obat antara OAT-OAD mampu menghambat satu sama lainnya. ${ }^{5}$ Terdapat interaksi obat dapat menimbulkan toksisitas ataupun penurunan efek terapi pengobatan sehingga pasien tidak merasa sehat kembali atau tidak cepat sembuh sebagaimana seharusnya, dengan kata lain dapat memengaruhi outcome klinis pasien. ${ }^{6,7}$ Menurut laporan Intitute of Medicine angka kejadian interaksi obat yang terjadi di klinik cukup besar. Kematian dapat terjadi karena efek samping pengobatan atau tata laksana yang dilakukan (termasuk akibat interaksi obat). ${ }^{8}$

Penelitian sebelumnya telah membuktikan bahwa rifampisin mengakibatkan peningkatan metabolisme OAD. Rifampisin itu mampu menginduksi Cythocrome p-45o (CYP450) yang dapat menurunkan konsentrasi obat-obatan dalam serum yang dimetabolisme oleh isoenzyme tersebut seperti OAD. Pemberian isoniazid (INH) mampu menimbulkan gejala neuropati serta pada pasien DM terdapat pula gejala neuropati. Obat antituberkulosis yang lainnya seperti etambutol akan menurunkan fungsi penglihatan seperti penurunan penglihatan dan buta warna. Pada pasien DM terdapat pula gejala retinopati. ${ }^{5,9}$

Tatar dkk.10 dan Siddiqui dkk.11 menunjukkan bahwa efek samping yang dapat ditimbulkan oleh OAT-OAD meliputi berat badan menurun, sakit dada, sesak napas, batuk berdarah, kehilangan nafsu makan, sakit kaki, gatal, erythematous rash, demam, sakit punggung, arthralgia, achilles pain, brurring vision, mual dan muntah, serta liver injury. Baghaei dkk. ${ }^{12}$ melaporkan efek samping kombinasi OAT dan OAD atau keluaran penatalaksanaan adalah kematian.

Data RSUD Al-Ihsan menunjukkan bahwa insidensi TB dengan DM adalah penyakit dengan komplikasi terbanyak. Rumah Sakit Umum Daerah (RSUD) Al-
Ihsan menjadi tempat rujukan daerah di sekitarnya untuk penatalaksanaan yang lebih lanjut dan menjadi pusat untuk pengambilan OAT yang diberikan dari pemerintah setempat. Berdasar atas paparan di atas tujuan penelitian ini mengetahui potensi interaksi obat antituberkulosis dan obat antidiabetes dengan efek samping obat pada pasien tuberkulosis-diabetes melitus di RSUD Al-Ihsan Bandung.

\section{Metode}

Penelitian yang digunakan adalah penelitian analitik observasional metode cross-sectional. Pengambilan sampel penelitian ini menggunakan total sampling dengan mengambil subjek penelitian pasien TB-DM yang telah memenuhi kriteria inklusi, yaitu didiagnosis TB-DM, mengonsumsi OAT-OAD bersamaan, data OAT-OAD yang lengkap pada rekam medis, dan juga pasien yang bersedia untuk mengisi kuesioner dengan lengkap. Responden berjumlah 30 orang.

Bahan penelitian untuk data efek samping obat pada pasien TB-DM menggunakan data primer, yaitu kuesioner yang diberikan pada pasien TB-DM di Poli Directly Observed Treatment Short-course (DOTS) RSUD Al-Ihsan periode April-Mei 2018. Kuesioner tersebut telah dilakukan uji validitas dan uji reliabilitas. Data OAT-OAD diambil melalui data sekunder, yaitu rekam medik. Kategori efek samping ringan: gejala hilang tanpa menggunakan obat atau hilang dengan istirahat; efek samping sedang: gejala hilang dengan konsumsi obat; efek samping berat: gejala tidak hilang setelah istirahat dan minum obat sehingga perlu datang ke dokter untuk mengatasi gejala efek samping. ${ }^{13}$

Data potensi interaksi obat tersebut diambil dari data obat yang sudah tercantum di dalam rekam medik, kemudian diolah menggunakan software LexiInteract pada smartphone yang sebelumnya dilakukan proses registrasi untuk dapat mengakses aplikasi LexiInteract. Penelitian ini menggunakan metode analisis data chi-square. Penelitian ini telah mendapatkan izin etik dari Komite Etik Kesehatan Fakultas Kedokteran Unisba dengan Nomor 311/Komite Etik.FK/III/2018.

\section{Hasil}

Penelitian ini dilaksanakan di Poli DOTS RSUD AlIhsan yang dimulai pada bulan April-Mei 2018.

Tabel 1 Karakteristik Umum Pasien TB-DM berdasar atas Jenis Kelamin dan Usia Pasien di Poli DOTS RSUD AlIhsan

\begin{tabular}{cc}
\hline Variabel & Frekuensi \\
\cline { 2 - 2 } & $\mathbf{n = 3 0}$ \\
\hline Jenis kelamin & \\
Laki-laki & 10 \\
Perempuan & 20 \\
Usia pasien (tahun) & 6 \\
40-49 & 12 \\
$50-59$ & 11 \\
$60-69$ & 1 \\
$>70$ & \\
\hline
\end{tabular}


Pasien TB-DM didominasi oleh pasien perempuan sejumlah 20 dari 30 orang pasien. Karakteristik usia pasien didominasi oleh pasien dengan rentang usia 50-69 (23 dari 30 orang) tahun (Tabel 1).

\begin{tabular}{cc} 
Tabel 2 & \multicolumn{2}{l}{ Karakteristik Pengobatan pada } \\
Pasien TB-DM di Poli DOTS RSUD Al- \\
Ihsan Periode April-Mei 2018
\end{tabular}

Jumlah obat yang dikonsumsi oleh pasien TB-DM didominasi oleh penggunaan 3 jumlah obat oleh 17 dari 30 orang pasien. Lama pengobatan yang dijalani oleh pasien didominasi dengan waktu pengobatan $<6$ bulan (23 dari 30 orang, Tabel 2).

Tabel 3 Derajat Potensi Interaksi OAT-OAD yang Memungkinkan Terjadi pada Pasien TB-DM di Poli DOTS Al-Ihsan Periode April-Mei 2018

\begin{tabular}{lc}
\hline Potensi Interaksi Obat & $\mathbf{n = 3 0}$ \\
\hline Tidak ada interaksi & 10 \\
Ringan & 0 \\
Sedang & 8 \\
Berat & 12 \\
\hline
\end{tabular}

Tabel 4 Derajat Efek Samping Obat yang Dirasakan Pasien TB-DM di Poli DOTS RSUD Al-Ihsan periode AprilMei 2018

\begin{tabular}{lc}
\hline Dirasakan Pasien & n \\
\hline Efek samping & \\
Mual & 16 \\
Muntah & 9 \\
Tidak nafsu makan & 9 \\
Konstipasi & 4 \\
Kesemutan jari kaki & 9 \\
Kesemutan jari tangan & 8 \\
Sakit pada dada & 3 \\
Jantung berdebar & 9 \\
Sakit pada tulang belakang & 5 \\
Sakit pada ruas jari & 6 \\
Gatal & 15 \\
Tidak ada efek samping & 9 \\
Derajat & 7 \\
Tidak ada efek samping & 10 \\
Ringan & 6 \\
Sedang & 7 \\
Berat & \\
\hline
\end{tabular}

Keterangan: efek samping yang dirasakan dapat lebih dari 1.
Tabel 3 menyimpulkan bahwa potensi interaksi obat yang memungkinkan terjadi pada pasien TB-DM adalah potensi interaksi obat berat sejumlah 12 dari 30 orang.

Efek samping yang paling dirasakan oleh pasien adalah mual sebanyak 16 dari 30 pasien. Efek samping yang dirasakan oleh pasien berjumlah lebih dari satu gejala. Data derajat efek samping yang paling banyak dirasakan oleh pasien adalah derajat ringan sejumlah 10 dari 30 kasus (Tabel 4).

Tabel 5 menunjukkan bahwa hasil uji statistik chi square pada kelompok penelitian di atas diperoleh $\mathrm{p}=0,146$ yang berarti tidak bermakna secara statistik, berarti tidak terdapat perbedaan efek samping antara kelompok interaksi obat ringan, sedang, dan berat serta tidak terdapat interaksi obat. Tidak terdapat hubungan antara derajat potensi obat yang mungkin terjadi pada pasien dan efek samping obat yang timbul pada pasien.

\section{Pembahasan}

Interaksi obat dapat terjadi apabila efek obat berganti oleh aktivitas obat lain, makanan, minuman, atau zat kimia lain. Gejala efek samping karena penggunaan obat dapat ditimbulkan oleh beberapa faktor seperti jumlah obat, dosis obat yang diberikan, interaksi obat dengan obat atau obat dengan makanan, dan juga obat dengan minuman. ${ }^{14}$ Teori Stockley menjabarkan bahwa potensi interaksi obat dengan obat itu bukan menjadi penyebab tunggal yang mampu menyebabkan efek samping terhadap pasien. Efek samping yang dirasakan pasien dapat diakibatkan oleh pengaruh dosis yang diterima, kepatuhan pasien, dan juga cara penggunaan obat yang tidak tepat dapat menimbulkan efek samping pada pasien.

Penelitian serupa sebelumnya pernah dilaksanakan bahwa terdapat hubungan bermakna potensi interaksi dengan efek samping yang timbul pada pasien, Siddiqui dkk. ${ }^{11}$ melakukan penelitian dengan memakai metode cohort dengan cara pendekatan populasi dan pengukuran secara berkala dari gula darah pasien. Hasil penelitian dinyatakan bahwa terdapat hubungan yang bermakna antara potensi interaksi obat dan efek samping yang timbul terhadap pasien TB-DM (OR: 3,578; IK 95\%: 1,114-11,4; $\mathrm{p}=0,032)$. ${ }^{11}$ Pada penelitian itu dilakukan pemeriksaan rutin efek samping yang dirasakan pasien dan kadar glukosa darah pada pasien secara berkala. Pemantauan dalam waktu cukup lama tersebut membuat hasilnya menjadi semakin akurat dan terpantau secara medis.

Efek samping obat tidak hanya dipengaruhi oleh potensi interaksi obat karena penelitian sebelumnya dinyatakan bahwa efek samping yang dirasakan oleh pasien dipengaruhi oleh jumlah obat yang ditelan. Pasien yang menerima $>5$ obat memungkinkan 10,278 kali lebih tinggi mengalami efek samping obat yang disebabkan oleh interaksi yang terjadi. ${ }^{7}$ Penambahan jumlah obat yang dikonsumsi pasien semakin banyak menunjukkan bahwa kadar dosis yang diterima pasien akan menjadi semakin tinggi sehingga memungkinkan terjadi efek samping obat yang dirasakan oleh pasien.

Riza dkk. ${ }^{15}$ menyatakan bahwa untuk melaksanakan terapi pada pasien TB-DM tidak hanya dilakukan 
Tabel 5 Analisis Chi-square Potensi Interaksi OAT-OAD dengan Efek Samping yang Dirasakan Pasien TB-DM di Poli DOTS RSUD Al-Ihsan Periode April-Mei 2018

\begin{tabular}{|c|c|c|c|c|c|}
\hline \multirow[b]{2}{*}{$\begin{array}{c}\text { Potensi Interaksi } \\
\text { Obat }\end{array}$} & \multicolumn{4}{|c|}{ Efek Samping Obat } & \multirow[b]{2}{*}{ Nilai p } \\
\hline & $\begin{array}{c}\text { Tidak ada } \\
\mathbf{n}=7\end{array}$ & $\begin{array}{c}\text { Ringan } \\
\mathbf{n}=\mathbf{1 0}\end{array}$ & $\begin{array}{c}\text { Sedang } \\
n=6\end{array}$ & $\begin{array}{c}\text { Berat } \\
\mathbf{n}=7\end{array}$ & \\
\hline $\begin{array}{l}\text { Tidak ada potensi } \\
\text { interaksi }\end{array}$ & 5 & 4 & $\mathrm{O}$ & 1 & 0,146 \\
\hline Ringan & $\mathrm{O}$ & O & O & $\mathrm{O}$ & \\
\hline Sedang & 1 & 2 & 2 & 3 & \\
\hline Berat & 1 & 4 & 4 & 3 & \\
\hline
\end{tabular}

secara farmakologis, tetapi dapat juga dikombinasikan dengan terapi nonfarmakologis dengan mengubah gaya hidup pasien. Penjelasan penelitian sebelumnya dapat menjadi acuan untuk membuktikan bahwa efek samping obat yang terjadi pada pasien tidak hanya dipengaruhi oleh potensi efek samping yang dapat timbul, tetapi dipengaruhi oleh banyak faktor seperti gaya hidup yang tidak diubah dan membuat efek samping obat tersebut terjadi kepada pasien.

\section{Simpulan}

Tidak terdapat hubungan antara potensi interaksi obat dan efek samping yang dirasakan pasien di Poli DOTS RSUD Al-Ihsan periode April-Mei 2018.

\section{Saran}

Pemberian OAT-OAD dapat diberikan pada pasien TBDM, tetapi tetap melihat secara komprehensif untuk memberikan obat pada pasien seperti usia pasien, kondisi pasien, dan kepatuhan pasien menelan obat. Potensi interaksi obat hanya salah satu aspek yang harus diperhitungkan sehingga dapat mengurangi efek samping yang dirasakan oleh pasien TB-DM.

\section{Daftar Pustaka}

1. Depkes RI. InfoDatin. Tuberkulosis temukan obati sampai sembuh. Jakarta: Depkes RI; 2016.

2. WHO. Global tuberculosis report 2017: Leave No One behind - Unite to End TB.; 2017.

3. Kementerian Kesehatan RI. Data dan informasi profil kesehatan Indonesia 2016. Jakarta: Kementeri Kesehat RI; 2016 (diunduh 17 Desember 2017). Tersedia dari: http://www.depkes.go.id/ resources/download/pusdatin/lain-lain/Data dan Informasi Kesehatan Profil Kesehatan Indonesia 2016 - smaller size - web.pdf.

4. Rahmat A, Aswar A, Nawas A, Sihombing B, Sulistiany E, Yunir E, dkk. Tuberkulosis dengan diabetes mellitus (diunduh 17 Desember 2017). Tersedia dari: http://www.tbindonesia.or.id/
tbidcnt/uploads/2017/o2/Buku-PetunjukTeknis-Penemuan-Pasien-TB-DM-Di-FasilitasKesehatan-Rujukan-Tngkat-Lanjut.pdf.

5. Wijaya I. Tuberkulosis paru pada penderita diabetes melitus. CDK-229. 2015;42(6):412-7.

6. Lisiana N. Studi penggunaan obat anti tuberkulosis pada pasien TB-HIV/AIDS di RSUP Sanglah Denpasar tahun 2009. JMPK. 2011;14(02):99-107.

7. Handayani K. Analisis potensi interaksi obat diabetes melitus pada resep obat pasien rawat jalan di RSAL Dokter Mintohardjo. Jakarta: UIN; 2015.

8. Prasetya AANPR, Karsana AAR, Swastini DA. Kajian interaksi obat pada pengobatan pasien gagal ginjal kronis hipertensi di RSUP Sanglah Denpasar tahun 2007. JFU. 2012;1(1):9-15.

9. Yanti Z. Pengaruh diabetes melitus terhadap keberhasilan pengobatan TB paru di Puskesmas Tanah Kalikedinding. J Berkala Epidemiol. 2017 Mei;5(2):163-73.

10. Tatar D, Senol G, Alptekin S, Karakurum C, Aydin M, Coskunol I. Tuberculosis in diabetics: features in an endemic area. Jpn J Infect Dis. 2009;62:4237.

11. Siddiqui AN, Khayyam KU, Sharma M. Effect of diabetes mellitus on tuberculosis treatment outcome and adverse reactions in patients receiving directly observed treatment strategy in India: a prospective study. Biomed Res Int. 2016;2016:7273935. doi: 10.1155/2016/7273935.

12. Baghaei P, Marjani M, Javanmard P, Tabarsi P, Masjedi MR. Diabetes mellitus and tuberculosis facts and controversies. J Diabetes Metab Disord. 2013;12(1):1-8. (diunduh 17 Februari 2018). Tersedia dari: http://www.jdmdonline.com/ content/12/1/58

13. U.S. Food and Drug Administration (FDA). Classification of side effect of drugs. United States: National Library of Medicine; 2018.

14. Preston CL. Stockley 's drug interactions. Edisi ke-11, Pharmaceutical Press; 2016.

15. Riza AL, Pearson F, Ugarte-Gil C, Alisjahbana B, van de Vijver S, Panduru NM, dkk. Clinical management of concurrent diabetes and tuberculosis and the implications for patient services. Lancet Diabetes Endocrinol. 2014 Sep;2(9):740-53. doi: 10.1016/ S2213-8587(14)70110-X. 